\title{
IMPACT OF FOREIGN DIRECT INVESTMENT, IMPORTS AND TARIFF DEREGULATION ON EXPORTS AMONG PIONEERING ASEAN MEMBERS: PANEL DATA ANALYSIS
}

\author{
James Asirvatham \\ Universiti Malaya \\ Rajah Rasiah* \\ Universiti Malaya \\ Govindamal Thangiah \\ Universiti Malaya \\ Navaz Naghavi \\ Universiti Malaya
}

\begin{abstract}
Following the successful development of the first-tier Newly Industrialized economies of South Korea and Taiwan, governments have gradually moved from import-substitution policies to export-led or export-led import substitution policies. The Association of Southeast Asian nations are no exception as the rapid pace of trade liberalization has been referred to as the prime driver of economic growth in these countries. While the industrial policies of these countries may not be as effective as those of the first-tier NIEs, the pioneering ASEAN members of Indonesia, Malaysia, Philippines, Singapore and Thailand have enjoyed rapid growth and structural change since the 1970s. Indeed, Singapore's per capita income has remained higher than that of South Korea and Taiwan. Indonesia, Malaysia, Philippines and Thailand became middle income countries by the turn of the millennium. Hence, using panel data over the period 1970-2015 this paper seeks to analyze the influence of foreign direct investment, imports and tariff deregulation on export growth among the five pioneering ASEAN members. The results show that open trade policies in general and increases in FDI, imports and tariff deregulations has helped the ASEAN-5 stimulate exports.
\end{abstract}

Keywords: Exports; Foreign direct investment; Imports; Tariffs; ASEAN.

\section{INTRODUCTION}

The Association of Southeast Asian nations (ASEAN) was formed in 1967 with the pioneering members of Indonesia, Malaysia, Philippines, Singapore and Thailand in 1967 as a security organization to ward of the threat of communism that became apparent from communist Vietnam, and later Cambodia and Laos. However, as Vietnam became entrenched as a communist nation the focus of ASEAN shifted increasingly towards economic interests. The transformation became formal when the five pioneering members

* Corresponding Author: Rajah Rasiah, Department of Development Studies, Faculty of Economics and Administration, University of Malaya, Kuala Lumpur, 50603, Malaysia. Email: rajah@um.edu.my 
and Brunei formed the ASEAN Free Trade Area (AFTA) in 1992. Foremost in the arrangement was a vigorous but joint effort to deregulate and streamline tariff procedures among members so as to stimulate trade and foreign investment. Vietnam, Cambodia, Laos and Myanmar subsequently joined to AFTA process.

Also, important is the leading role played by the pioneering ASEAN members, whim henceforth we refer to as ASEAN-5, to switch from import-substitution to export orientation as the engine of growth since 1965 by Singapore, 1970 by Malaysia and the Philippines, since 1980 by Thailand, and 1990 by Indonesia. Singapore pursued exportorientation once it left the Malaysia coalition in 1965. Although some of the countries, especially Malaysia and Indonesia did continue with import-substitution in heavy industries, the prime driver of economic growth in these countries had already become export-orientation. Indeed, export-processing zones mushroomed in the ASEAN since the 1970s.

In a previous paper we examined the impact of the AFTA process on foreign direct investment (Asirvatham, Rasiah and Adamu, 2016). In this paper, we seek to investigate the determinants of trade in the pioneering five ASEAN. Using the macroeconomic variables of imports, foreign direct investment and aggregate tariffs, and panel data of the five countries over the period 1970-2015 we seek to examine the determinants of exports in these countries. The rest of the paper is organized as follows. Section 2 reviews the extant literature on exports and the variable that cause it. Section 3 discusses the methodology and data used. The results and analysis follow next. The paper finishes with the conclusions finally.

\section{THEORETICAL CONSIDERATIONS}

Exports are generally accepted as a key determinant of GDP. However, for a number of decades there was dispute over whether GDP can be best stimulated through importsubstitution or export orientation. India (till the 1990s), China (till 1978), Russia (till 1991) and Cuba took import substitution as their prime strategy to stimulate GDP growth and structural change. There is consensus now that export-orientation at some point or in some form is critical to provide the market and competition to evolve competitiveness alongside GDP growth. Hence, the focus on the paper on exports.

Given that the pioneering five ASEAN members have sought to introduce and strengthen instruments to stimulate exports, it is worthwhile examining the variables that influence it. Indeed, tariffs in these countries have fallen since 1970, and especially since the introduction of AFTA. The macroeconomic variables generally considered to influence export growth are tariffs, imports and foreign direct investment. In this section we explain the theoretical rationale for the inclusion of these variables as factors that influence exports.

\subsection{Exports}

Building on Smith's (1776) notion of the division of labour being shaped by the size of the market, and the converse being equally right, Hirschman (1958) had argued that 
forward linkages within the national economy are not important as exports offer the scale and scope for the development of backward linkages. Indeed, Hirschman (1970) argued that nascent developing economies typically start with low backward linkages when investment (including foreign) occurs. Amsden (1983) used the machine tool industry in Taiwan to show evidence of the positive effect of the division of labour and markets on each other. It is then the task of national governments to evolve the absorptive capacity for domestic firms to develop the capabilities to supply export-oriented firms.

Emery (1967) had found a strong causal link between exports and Gross National Product among 50 countries over the period 1953-1963. Kilavuz \& Topcu (2012) went further to examine the statistical link between manufactured exports and GDP growth among 22 developing economies. They found that this positive relationship was only significant among high tech industries. Hirschman's (1970) work was later taken on by Helpman and Krugman (1985) and Grossman and Helpman (1991, 1993) who used quantitative models to show how export-oriented import-substitution (IS) policies can stimulate rapid economic growth.

However, neoclassical economics abandoned altogether the need to introduce IS policies on the grounds that it would distort the role of relative factor prices (see for example Bhagwati and Krueger, 1974; Krueger et al, 1981). Yet, neoclassical arguments have expounded the significance of both exports, as well as deregulation, which includes the removal of trade obstacles, such as tariffs and quotas. Hence, from the neoclassical lenses, not only are exports important to provide the market for demand-led production, they have to be stimulated under conditions of free trade.

\subsection{Foreign Direct Investment}

Foreign direct investment (FDI) was considered a destructive instrument among dependency economists in the 1960s and 1970s, which invoked passion among postcolonial leaders to refuse them entry into prioritized sections. The successful growth of South Korea and Taiwan was seen as a consequence of national policies that targeted domestic accumulation (Hamilton, 1983; Rasiah, 1988). However, the experience of SubSaharan African economies have largely been negative on this front. Both countries that attracted strong FDI inflows, such as Congo and Nigeria, and those that did not, such as Angola and Somalia did not achieve stable economic growth since independence; However, ASEAN economies have enjoyed a fairly positive invitational strategies, especially since the late 1980s so as to raise FDI shares in GDP in these countries.

FDI is viewed by some economists to enjoy the potential to synergize host economies while by other economists have claimed that they can crowd out domestic development of developing economies. On the one hand, Hirschman (1958), Caves (1974), Borensztein, de Gregorio \& Lee (1998), and Rasiah (1995) argued that FDI brings scarce capital, embodied technology, competition and demonstration effect to stimulate spillover at host economies. On the other hand, FDI can also crowd out domestic investment through backwash effects (Lall \& Streeten, 1977), thereby reducing banana republics to pyjama republics (Adam, 1975). 
More recent work on FDI shows that its impact on domestic accumulation depends on host country strategies (Lall, 1987; Rasiah, 1995). Using panel data from 105 countries over the period 1984-2000, Harding and Jervocik (2012) found that FDI helps raise the quality of exports. In the absence of domestic capabilities and the requisite technology policies FDI seeking resources, such as mining and agriculture, could cause the introduction of capital-intensive technologies to surmount problems of skills supply, poor infrastructure and security (Arrighi, 1994). In this regard, Rasiah (2004) showed evidence of superior expansion in exports, including in high value added activities by host nations that evolved the requisite high technology infrastructure. Hirschman (1970) had argued succinctly that it is the task of national governments to remove the obstacles and engender the conditions for accumulation.

\subsection{Imports}

While excessive imports can burden countries with balance of payments problems, it is viewed by some economists to be the channel through which firms absorb capital equipment and ram materials to transform them to manufactured goods. Krugman (1980), and Grossman and Helpman (1993) made persuasive arguments on how export-oriented import-substitution offered the scale and scope to build domestic capabilities in successful industrializers. Indeed, imports of capital equipment were a key source of learning and production utilization in the development of export capabilities in South Korea and Taiwan.

Several countries have achieved significant learning and technology flows from superior innovation networks to inferior innovations through imports of capital equipment and technology - through acquisition and foreign direct investment. In macroeconomic terms, imports as a whole has been shown to stimulate export growth (see Krugman, 1986; Grossman and Helpman, 1991).

Imports are also considered to offer productive competition to stimulate production and exports. In fact, a number of markets only allow exports into their economies if reciprocal imports are allow into their national economies (Steinwender, 2015). Indeed, Rasiah $(1998,2009)$ has shown how export-led growth based on processing of imported inputs helped make Indonesia, Malaysia, Philippines and Thailand competitive in high technology manufactured exports, albeit only in low value added segments of the value chains. Within ASEAN, imports of inputs, including high technology intermediate products, such as fabricated wafers and assembly machines, were critical in supporting the production of exports of integrated circuits and electrical appliances (Rasiah, Yap and Chandran, 2014).

\subsection{Tariffs}

Mainstream literature posits that trade openness will promote economic growth (Krueger, 1980). However, the effects of international trade on economic growth have remained the subject of intense debate. Still, the main question of whether (and how) trade enhances growth remains vague, as the conclusions of both theoretical and empirical studies are highly sensitive to changes in the assumptions made, the variables used to measure trade openness, the sample data used, and the econometric technique employed (see, for 
example, Grossman \& Helpman, 1991; Matsuyama, 1992; Rasiah, 1995; Walde \& Wood, 2005; Rodriguez \& Rodrik, 2001; Yanikkaya, 2003). Notably, most of the analysis on this debate involves trade measures regarding export and import volumes or shares, trade policies regarding tariffs or custom barriers, and related measures of trade openness.

While empirical measures of trade characteristics or trade patterns and configurations have been fraught with problems stemming from measurement problems associated with tariff structures. Southeast Asia's experiment with regionalism has resulted in rapid reduction in tariffs between ASEAN member countries but there is little information on the volume of trade going through each of these tariffs. The problems are magnified when the measurement tools are different at different periods, and across countries.

Attempts to use a normalized index from several proxies, such as tariffs, the Grubel-Lloyd index, and revealed comparative advantage have not necessarily improved the measures used to estimate openness. Nevertheless, while it is impossible to produce an exhaustive instrument to capture openness, it is not less accurate than the composite indices used by others to use a common instrument that is deemed to approximate the neoclassical proxy of trade openness, which is aggregate tariffs if the same instrument is used across the years and between countries. Yet, no one has actually used extensively a simple or weighted tariffs in examining its effects on exports among ASEAN members.

Clearly, the leading exponent among global organizations that strongly advocate tariff deregulation among the various instruments in economics to stimulate growth is the World Bank. Indeed, while acknowledging the extent of interventions that South Korea and Taiwan undertook when the World Bank (1993) successfully industrialized, they considered the ASEAN economies of Indonesia, Malaysia, Philippines, Singapore and Thailand as the better models for imitation. Indeed, these economies used less tariffs and other import-substitution measures to promote economic growth.

Overall, there is sufficient argument and evidence to test for the influence of FDI, imports and tariffs on export growth for the following reasons. Firstly, the rapid industrializers of South Korea and Taiwan relied heavily on selective interventions, including in the promotion of IS industrialization. Secondly, although FDI inflows were allowed, the focus of industrialization in these countries was national capital. In South Korea FDI was prevented from strategic industries in the 1970s. In Taiwan there were no measures to restrict FDI inflows, but the industrial research institutes stimulated the development of national firms since 1974. Thirdly, the nature of deregulation that have spread in ASEAN has reduced the opportunity to undertake profound IS policies. Indeed, the pioneering ASEAN five have experienced substantial trade deregulation since the formation of AFTA in 1992.

\section{METHODOLOGY AND DATA}

Instead of undertaking a time series assessment of the ASEAN-5, we adopt a panel analysis that combines the time series across the five countries. A panel data analysis has the merit of using information concerning cross-section and time-series analyses. It can also take heterogeneity of each-sectional unit explicitly into account by allowing for 
individual-specific effects (Davidson \& Mackinnon, 2004) and gave more variability, less collinearity among variables, more degrees of freedom, and more efficiency (Baltagi, 2001). The five Southeast Asian economies of current study (Malaysia, Singapore, Indonesia, Thailand, Philippines) have more or less similarity in culture and geographical proximity, their rapid economic growth during the past two decades. That is why we pool their five cross-sectional data over 46-year period (1970-2015) into a panel data set and then use panel data regression to examine the most influential factors to increase export in these countries.

The descriptive statistic of the variables are highlighted in Table 1. The country ID did not vary over time (within variances $=0$ ) and the time variable (Years) did not vary over country (between variance $=0$ ). The average of export and FDI (natural logarithm) is equal, 20.9, while the mean value of import (natural logarithm) is lower than that of tariff $\left(\mathrm{Mean}_{\text {import }}=24.28, \mathrm{Mean}_{\text {tariff }}=39.62\right)$. Export, FDI, import and tariff are all time variants and has higher within country variation over time than between country variation over time. The minimum time period is 1 year and the maximum time period is 46 years and there are minimum 1 and maximum 5 countries assessed in the data. Export, FDI, Import (all in natural logarithm) has a minimum value of 15.23, 15.23, 21.11 and 0 respectively while the maximum values are $24.95,24.95,26.96$ and 150 respectively.

Table 1: Descriptive Statistic

\begin{tabular}{cccccc}
\hline \hline Variable & Variance & Mean & Std. Deviation & Min & Max \\
\hline Country ID & overall & 3 & 1.42 & 1 & 5 \\
& Between & & 1.58 & 1 & 5 \\
& Within & & 0 & 3 & 3 \\
\hline Time (Year) & overall & 23.5 & 13.3 & 1 & 46 \\
& Between & & 0 & 23.5 & 23.5 \\
& Within & & 13.3 & 1 & 46 \\
\hline LnExport & overall & 20.9 & 2.049 & 15.23 & 24.95 \\
& Between & & 0.865 & 19.85 & 22.15 \\
& Within & & 1.89 & 16.29 & 24.44 \\
\hline LnFDI & overall & 20.9 & 2.054 & 15.23 & 24.95 \\
& Between & & 0.87 & 19.85 & 22.15 \\
& Within & & 1.90 & 16.28 & 24.48 \\
\hline LnImport & overall & 24.28 & 1.34 & 21.11 & 26.96 \\
& Between & & 0.47 & 23.62 & 24.94 \\
& Within & & 1.27 & 21.05 & 26.42 \\
\hline Aggregate & overall & 39.62 & 37.49 & 0 & 150 \\
Tariff & Between & & 20.63 & 3.71 & 54.12 \\
& Within & & 32.62 & -3.41 & 140.59 \\
\hline \hline
\end{tabular}

\subsection{Panel data: Fixed Effect Approach}

When we estimate panel data regression models, we consider the assumptions about the intercept, the slope coefficients, and the error term. In practice, the estimation procedure is either the fixed effects model or the random effects model (Greene, 2003). The fixed effects model (FEM) assumes that the slope coefficients are constant for all cross section 
units, and the intercept varies over individual cross-section units but does not vary over time. For our application, the FEM can be written as follows:

$$
y_{i t}=\alpha_{i}+x_{i t} \beta+u_{i t}
$$

where $y_{i t}$ is dependent variable, $i$ is the $i$ th cross-section unit and $t$ is the time of observation. The intercept, $\alpha_{i}$ takes into account of the heterogeneity influence from unobserved variables which may differ across the cross-section units. The $x_{i t}$ is a row vector of all endogenous independent variables. The $\beta$ is a column vector of the common slope coefficients for the group of five economies. The error term $u_{i t}$ follows the classical assumptions that $u_{i t} \sim N\left(0, \delta_{u}^{2}\right)$. The FEM is estimated by the method of the least squares dummy variable (LSDV).

\subsection{Random Effect Approach}

The random effects model (REM) also assumes that the slope coefficients are constant for all cross-section units, but the intercept is a random variable, that is, $\alpha_{i}=\alpha+\varepsilon_{i t}$ where $\alpha$ the mean value for the intercept of all cross-section units is, and $\varepsilon_{i t}$ is a random error term which reflects the individual differences in the intercept value of each cross-section unit, and $\varepsilon_{i} \sim N\left(0, \delta_{\varepsilon}^{2}\right)$.

Substituting into Eq. (1), we have REM in Eq. (2):

$$
y_{i t}=\alpha+x_{i t} \beta+v_{i t}
$$

where $v_{i t}=\varepsilon_{i t}+u_{i t}$. It has been shown that $v_{i t}$ and $v_{i s}($ for $t \neq s)$ are correlated, so the REM is estimated by the method of generalized least squares.

We use both FEM and REM to estimate the panel data using lnexport, lnfdi, and lnimport for five ASEAN countries as a group. We also apply the Hausman test to choose between FEM and REM estimations before implementing Breuch-Pagan test and Pesaran's test of cross sectional independence. The null hypothesis in the Hausman test is that the correlated REM is appropriate. It is a Chi-square test. If the null hypothesis is rejected, then we use FEM estimation.

Since the model uses panel data techniques, it is likely to suffer from autocorrelation. Since there is a controversy in the literature if the FDI and trade are substitutes or complements, the likelihood of multicollinearity between import and FDI should be investigated. Diagnostic tests was performed to ensure that the results do not suffer from any of the aforementioned problems. Results of diagnostic tests namely Breush-Pagan and Pesaran adduce that data is free from Multi-linearity and Serial Correlations. In our model, export is dependent variable, and FDI, Import and Tariff are the independent variables.

$$
\text { Export }_{i t}=\alpha+\beta_{1} \operatorname{Im}_{\text {port }}+\beta_{2} F D I_{i t}+\text { Tarrif }_{i t}+v_{i t}
$$

Since the variables have the VIF lower than the admissible level, there is no problem of multicollinearity affecting the regression results (Table 2 ). 
Table 2: Multicollinearity test

\begin{tabular}{|c|c|c|}
\hline Variables & " VIF & $1 / \mathrm{VIF}$ \\
\hline LNFDI & 5.39 & 0.185 \\
\hline LNIMORT & 4.99 & 0.200 \\
\hline TARIFF & 3.03 & 0.329 \\
\hline MEAN VIF & & \\
\hline
\end{tabular}

Source: Computed from data gathered from World Bank (2016), ASEAN secretariat, and UNCTAD (2016).

To check if there is serial correlation between different cross-sections, we applies the Breusch and Pagan test. The test checks if $\operatorname{var}(\mathrm{u})=0$. If the variance of errors between different sections are equal to zero means the cross sections are not correlated. The probability statistics for the test equals to zero. (Prob $>$ chibar $2=0.00$ ) and the null hypothesis of the existing the serial correlation is rejected.

\section{RESULTS AND ANALYSIS}

In this section, we report the empirical results based on a pooled data for 5 ASEAN countries over the period of 1970-2015 (see Table 3). We applied both fixed effect and random effect models. The Hausman test performed to compare the fixed effects model and the random effects one recommends the latter. The null hypothesis of Hausman test indicates that the random effect is more prior to fixed effect. The Hausman test results shows that the probability statistic equals to 0.319 , which denotes that the null hypothesis cannot be rejected. Random effect regression shows that Import and FDI are two vital influences in promoting exports in the ASEAN-5 as a group. As shown in Table 3, the magnitude of the effects of variables is statistically significant. The higher coefficient value of these variables is affirms their substantial influence on exports from these countries. For example, the results indicate that a $1.0 \%$ increase in imports will raise exports by $0.1 \%$. Indeed, much of the manufactured exports in electronics, and clothing and textiles from these countries depend on imports of capital equipment, fabricated wafers, and textile fibre, yarn and fabric (Rasiah, 2009, 2012).

FDI shows a higher influence on exports. The estimated coefficient for FDI is 0.9, which indicates that a $1.0 \%$ percent increase in FDI will lead to an increase of $0.9 \%$ in exports. These results are not surprising as foreign firms primarily operating in export processing zones have accounted for the bulk of manufactured exports from these countries (Rasiah, 1998, 2010). The only concern facing this reality is the lack of technological upgrading to support structural transformation from low to high value added activities.

The coefficient of tariffs has the right negative sign and is significant but is too small, suggesting its marginal influence. While the lowering of tariffs has improved exports from the ASEAN-5, it appears not as critical as FDI and imports. While the results provide statistical proof for open economy policies, it also shows that exports from deregulating economies will eventually be stimulated more by other factors. By and large, the current study supports those strand of literature supporting the positive influence of FDI on export growth. As proved here, the first and foremost determinant of export is FDI. The main reason underlying the positive effect lies in the export oriented Multinational companies. Since government provides facilities for export promotion, such facilities also attracts 
foreign investors. While Singapore can be considered an export-processing Island, the remaining ASEAN-5 erected several export-processing zones to promote exports (Rasiah, 1998). These economies also offer double deductive incentives on taxes for exporting firms. In order to promote exports, governments can adopt FDI led export growth strategies with twin objectives of capturing the benefits of both FDI inflow and export growth. The results offer evidence that targeted import increment has been export promoting. Negative effect of tariff provides more support that in an open economy when the required goods can be imported with minimum tariffs, export also would be promoted.

Table 3: Model Estimation, Random and Fixed Effects

\begin{tabular}{ccc}
\hline \hline \multirow{2}{*}{ Variables } & \multicolumn{2}{c}{ Coefficient Values } \\
\cline { 2 - 3 } & Random Effects & Fixed Effects \\
\hline LNFDI & $0.873 *(0.03)$ & $0.870 *(0.03)$ \\
LNIMPORT & $0.131 *(0.04)$ & $0.129 *(0.04)$ \\
TARIFF & $-0.001 * *(0.002)$ & $-0.001 * *(0.001)$ \\
INTERCEPT & $-0.392(0.68)$ & $-0.353(0.88)$ \\
Observations & 222 & 222 \\
Groups & 5 & 5 \\
R-sq overall & 0.79 & 0.78 \\
\hline
\end{tabular}

Hausman test

0.319 (Random Effect)

(Recommended)

Notes: Number in the parenthesis are standard errors; * and ** indicates significance at $1 \%$ and $10 \%$ respectively.

Source: Computed from data gathered from World Bank (2016), ASEAN secretariat, and UNCTAD (2016).

It is clear that all three variables, i.e. FDI, imports and tariffs have influenced the growth of exports from the ASEAN-5. While increasing openness have indeed stimulated export growth, evidence shows that the governments intervened, albeit mildly to promote FDI. Generous tax holidays, subsidized infrastructure initially were enjoyed by foreign firms in all the ASEAN-5, while in Singapore and Malaysia also R\&D grants to stimulate upgrading (Rasiah, 2009). It can also be argued that the early provision of financial incentives in these small economies as measured by GDP to promote exports since 1965 in Singapore, since 1971 in Malaysia and the Philippines, since 1985 in Thailand and since 1990 in Indonesia (especially in the Islands of Batam and Bintan) were also targeted at reducing the risks of operating at foreign sites that did not offer much markets domestically (Rasiah, 1995). In addition, Indonesia, Malaysia, Philippines and Thailand also benefitted from the appreciation in the currencies of Japan, South Korea, Singapore and Taiwan following the Plaza Accord in 1985. There was an avalanche of FDI inflows into these countries as the national governments also depreciated their currencies.

\section{CONCLUSIONS}

The evidence is clear cut that trade liberalization and promotion of FDI has had a positive impact on exports in the ASEAN-5. FDI showed the highest impact on export growth so that a $1.0 \%$ increase in it raised exports by $0.9 \%$ over the period 1970-2015. Imports came second with a $1.0 \%$ rise leading to an increase of $0.1 \%$ in exports. The impact of tariffs 
was marginal, which is largely a consequence of these economies having deregulated significantly especially from 1992 when AFTA was formed.

Since governments have played an important role to favour capital by offering generous incentives rather than subscribing to an out and out neoclassical advocacy of relative prices (markets), a combination of both may be the answer. One unanimous conclusion is that sticking to just import-substitution shall be a recipe for economic waste. In line with the arguments of Smith (1776), Hirschman (1958, 1970), Krugman (1980), Helpman and Krugman (1985), Grossman and Helpman (1993) and Rasiah (2010) targeting export markets is critical to sustain rapid growth and structural change. These developments, however, need not require the blanket opening of economies to the dictum of markets. The ASEAN-5 were interventionist in some ways, though distortions were not as extensive as those carried out in South Korea and Taiwan (World Bank, 1993).

Future work should focus on establishing the direction of causality by using the Granger causality test (Engle and Granger, 1987). Also, vital will be an exercise to compare the nature of policies pursued by the ASEAN-5 with South Korea and Taiwan as the latter became developed in one generation when the former were richer than the latter in the 1950s.

\section{REFERENCES}

Adam, G. (1975). Multinational corporations and worldwide sourcing. In H. Radice (Eds.), International firms and modern imperialism. Harmondsworth: Penguin Books.

Amsden, A. H. (1983). De-Skilling, Skilled Commodities, and the NICs' Emerging Competitive Advantage. The American Economic Review, 73(2), 333-337.

Arrighi, G. (1994). The long twentieth century: Money, power, and the origins of our times. New York: Verso.

Asirvatham, J. P., Rasiah, R., \& Adamu, I. M. (2016). Foreign Direct Investment, Trade Liberalization and Economic Growth: Evidence from the ASEAN-5. Journal of Economic Cooperation and Development, forthcoming.

Baltagi, B. H. (2001). Econometric analysis of panel data ( $2^{\text {nd }}$ ed.). New York: John Wiley and Sons.

Bhagwati, J., \& Krueger, A. (1974). Trade Strategies for Economic Development: The Asian Experience. New York: Macmillan.

Borensztein, E., de Gregorio, J., \& Lee, J. W. (1998). How does foreign direct investment affect economic growth? Journal of international Economics, 45(1), 115-135.

Caves, R. E. (1974). Multinational firms, competition, and productivity in host-country markets. Economica, 41(162), 176-193.

Davidson, R., \& MacKinnon, J. G. (2004). Econometrics theory and methods. New York: Oxford University Press.

Emery, R. F. (1967). The relation of exports and economic growth. Kyklos, 20(4), 470-486. Engle, R. F., \& Granger, C. W. J. (1987). Cointegration and Error Correction. Econometrica, 55(2), 251-276.

Greene, W. H. (2003). Econometric Analysis. Supper Saddle River, New Jersey: Prentice Hall. 
Grossman, G. M., \& Helpman, E. (1991). Quality ladders in the theory of growth. The Review of Economic Studies, 58(1), 43-61.

Grossman, G. M., \& Helpman, E. (1993). Innovation and growth in the global economy. MIT press.

Hamilton, J. D. (1983). Capitalist industrialization in East Asia's four little tigers. Journal of contemporary Asia, 13(1), 35-73.

Harding,T., \& Jervocik, B. S. (2012). Foreign Direct Investment and Export Upgrading. Review of Economics and Statistics, 94(4), 964-980.

Helpman, E., \& Krugman, P. R. (1985). Market Structure and Foreign Trade: Increasing returns, imperfect Competition and the international economy. Cambridge: MIT press.

Hirschman, A. O. (1970). Exit, voice and lovalty: Responses to Decline in Firms, Organizations, and States. Cambridge: Cambridge University Press.

Hirschman, A. O. (1958.). The strategy of economic development. New Haven: Yale University Press.

Kilavuz, E., \& Topcu, B. A. (2012). Export and Economic Growth in the Case of the Manufacturing Industry: Panel Data Analysis of Developing Countries. International Journal of Economics and Financial Issues, 2(2), 201-215.

Krueger, A. O., Lary, H. B, Monson, T., \& Akrasanee, N. (1981). Trade and Employment in Developing Countries: Individual Studies. Chicago: Chicago University Press.

Krugman, P. (1980). Scale economies, product differentiation and the pattern of trade. American Economic Review, 70(5), 950-959.

Krugman, P. (1986). Strategic Trade Policy and the New International Economics. Cambridge: MIT Press.

Lall, S. (1987). Learning to industrialize: The acquisition of technological capability by India. London: The Macmillan Press.

Lall, S., \& Streeten, P. (1977). Foreign investment, transnationals and developing countries. London: The Macmillan Press.

Matsuyama, K. (1992). Agricultural productivity, comparative advantage, and economic growth. Journal of economic theory, 58(2), 317-334.

Rasiah, R. (1988). The semiconductor industry in Penang: implications for the new international division of labour theories. Journal of Contemporary Asia, 18(1), 24-46.

Rasiah, R. (1995). Foreign Capital and Industrialization in Malaysia. Basingstoke: Macmillan.

Rasiah, R. (1998). The export manufacturing experience of Indonesia, Malaysia and Thailand: Lessons for Africa. United Nations Conference on Trade and Development Discussion Paper Volume 137.

Rasiah, R. (2004). Technological intensities in East and Southeast Asian electronics firms: Does network strength matter? Oxford development studies, 32(3), 433-455.

Rasiah, R. (2009). Expansion and Slowdown in Southeast Asian Electronics Manufacturing. Journal of the Asia Pacific Economy, 14(2), 123-137.

Rasiah, R. (2010). Industrialization in the second-tier NIEs. In R. Rasiah \& J. D. Schmidt (eds), The New Political Economy of Southeast Asia. Cheltenham: Edward Elgar.

Rasiah, R. (2012). Beyond the Multi-Fibre Agreement: How are workers in East Asia faring. Institutions and Economies, 4(3), 1-20.

Rasiah, R., Yap, X-S., \& Chandran, G. V. G. R. (2014). Crisis effects on the electronics industry in Southeast Asia. Journal of Contemporary Asia, 44(4), 645-663.

Rodriguez, F., \& Rodrik, D. (2001). Trade policy and economic growth: a skeptic's guide to the cross-national evidence. NBER Macroeconomics Annual 2000, 15, 261-338. 
Smith, A. (1776). An inquiry into the nature and causes of the wealth of the nations. London: Strahan \& Cadell.

Steinwender, C. (2015). The Roles of Import Competition and Export Opportunities for Technical Change. London School of Economics, Centre for Economic Performance (CEP) Discussion Paper number 1334.

Walde, K., \& Wood, C. (2005). The Empirics of Trade and Growth: Where are the Policy Recommendations? International Economics and Economic Policy, 1(2-3), 275-292.

World Bank (1993). The East Asian Miracle: Economic Growth and Public Policy. New York: Oxford University Press.

Yanikkaya, H. (2003). Trade openness and economic growth: a cross-country empirical investigation. Journal of Development economics, 72(1), 57-89. 